\title{
Intermédialités
}

Histoire et théorie des arts, des lettres et des techniques

Intermediality

History and Theory of the Arts, Literature and Technologies

\section{Inhabiting the Profile: Zach Blas' Facial Weaponization Suite}

\section{Sebastian Althoff}

Numéro 32, automne 2018

cacher

concealing

URI : https://id.erudit.org/iderudit/1058472ar

DOI : https://doi.org/10.7202/1058472ar

Aller au sommaire du numéro

Éditeur(s)

Revue intermédialités

ISSN

1920-3136 (numérique)

Découvrir la revue

Citer cet article

Althoff, S. (2018). Inhabiting the Profile: Zach Blas' Facial Weaponization Suite. Intermédialités / Intermediality, (32). https://doi.org/10.7202/1058472ar
Résumé de l'article

Cet article considère l'oeuvre Facial Weaponization Suite de Zach Blas (2011-2014) en relation avec la notion de gouvernementalité algorithmique afin de révéler une tactique de désidentification. Ce qu’on appelle la gouvernementalité algorithmique est l'exécution de la surveillance des individus par les big data, surveillance qui ne rend pas ceux-ci visibles, mais les contourne, compliquant ainsi tout engagement critique. Un tel engagement peut cependant être envisagé à travers la Facial Weaponization Suite. 


\title{
Inhabiting the Profile: Zach Blas' Facial Weaponization Suite
}

\author{
SEBASTIAN AlthofF
}

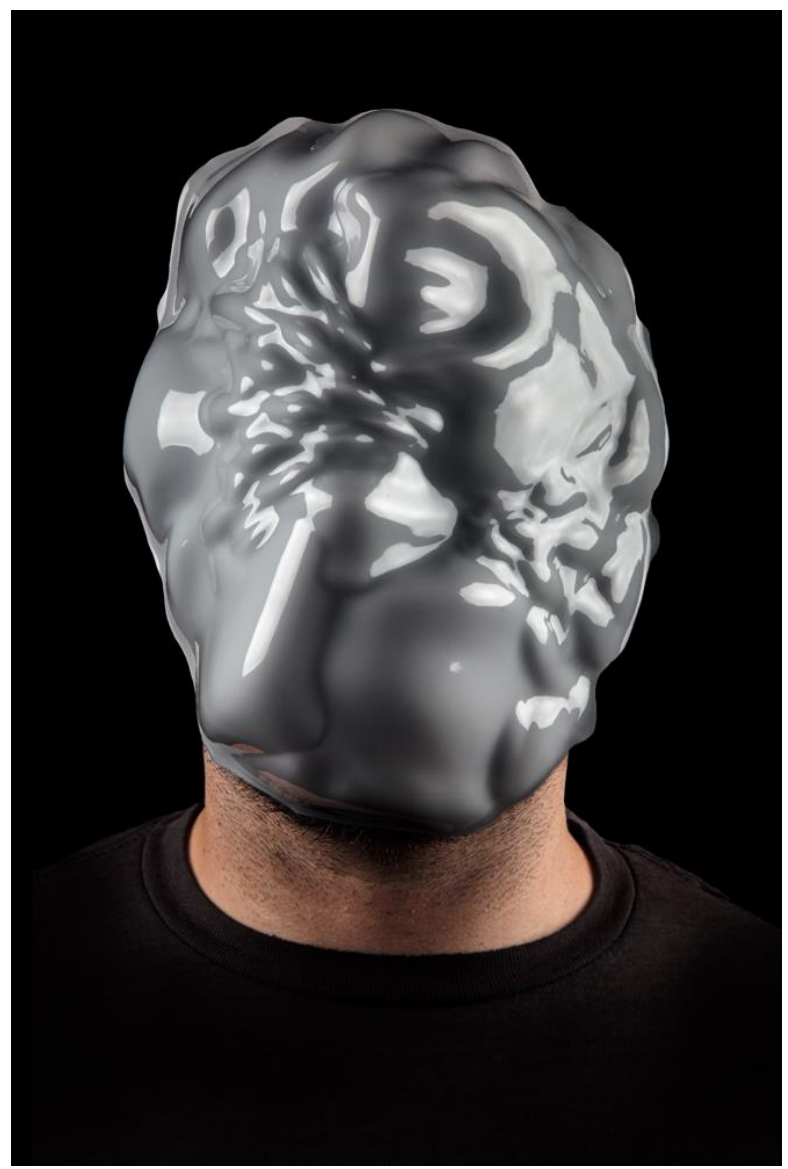

Fig. I. Facial Weaponization Suite: Mask - Ig May 2014, Mexico City, Mexico, photo by Christopher O'Leary. Reproduced with the kind permission of Zach Blas. 
$\mathrm{n}$ his text on the notion of "informatic opacity," the artist Zach Blas positions his work Facial Weaponization Suite (2OII-I4) (see Fig. I, 2, 3 and 4 ) ${ }^{\mathrm{I}}$ against a modern version of Michel Foucault's panopticon and argues that:

[b] oth the panopticon and NSA software control through an optical logic of making visible. While the panopticon employs the threat of continuous visibility as a disciplinary means to achieve docile conditioning, the NSA implements technical platforms to produce informatic visibilities on populations, which is the aggregation of data for identifying, categorizing, and tracking. ${ }^{2}$

In this article, I aim to read Blas' work partly against his own positioning. This seems necessary if one does not follow Blas' characterization of the current state of surveillance and perceives, rather, a difference between "big data, interactive biometric marketing, and the domestication of tracking and measuring technologies, exemplified in the Quantified Self movement." ${ }^{3}$ Differentiating these technologies and their implementations allows the recognition that the problem does not always have to concern visibility as is the case, for instance, with biometric technologies or the panopticon. Focusing on big data surveillance, this article claims that making measurable and comparable is not the same as making visible and identifiable. It is only through differentiating these technologies that one notices a different tactic in the Facial Weaponization Suite, namely a tactic of disidentification instead of "autonomous visibilities" 4 and becoming unrecognizable. Therefore, after introducing the Facial Weaponization Suite in the first part of this article, I will discuss the problem posed by Antoinette Rouvroy and Thomas Berns ${ }^{5}$ who argue that today's common implementation of big data surveillance, ranging from Facebook to the NSA, faces limited resistance not because of the ignorance of users,

I Zach Blas, Facial Weaponization Suite, mixed media installation, plastic masks, HDvideo with audio, $8 \mathrm{~min}$ II sec, photo documentation, 20II-I4.

${ }^{2}$ Zach Blas, "Informatic Opacity," The Journal of Aesthetics and Protest, no. 9, 20I4, http://www.joaap.org/issueg/zachblas.htm (accessed I2 June 20I8).

3 Ibid.

4 Ibid.

5 Antoinette Rouvroy and Thomas Berns, "Gouvernementalité algorithmique et perspectives d'émancipation. Le disparate comme condition d'individuation par la relation ? [Algorithmic Govermentality and Prospects of Emancipation: Disparateness as a precondition for individuation through relationships?]," trans. Elizabeth Libbrecht, Réseaux, "Politique des algorithmes, les métriques du web," vol. I, no. 177, 2013, p. 163-196, https://www.cairnint.info/article-E_RES_177_or63--algorithmic-governmentality-and-prospect.htm (accessed I9 September 2018). 
but because it produces no subjectivation and thus offers no discursive site from which to question this kind of surveillance. When positioned in relation to Rouvroy and Berns' analysis, the Facial Weaponization Suite appears to envision a tactic of establishing this discursive site and thus allowing an engagement with what Rouvroy and Berns term algorithmic governmentality. My argument proposes that the wearing of multiple faces, which Blas describes as a resistance to biometric facial recognition, can then be read as the inhabitation of the profile that is itself constructed through the combination of diverse data.

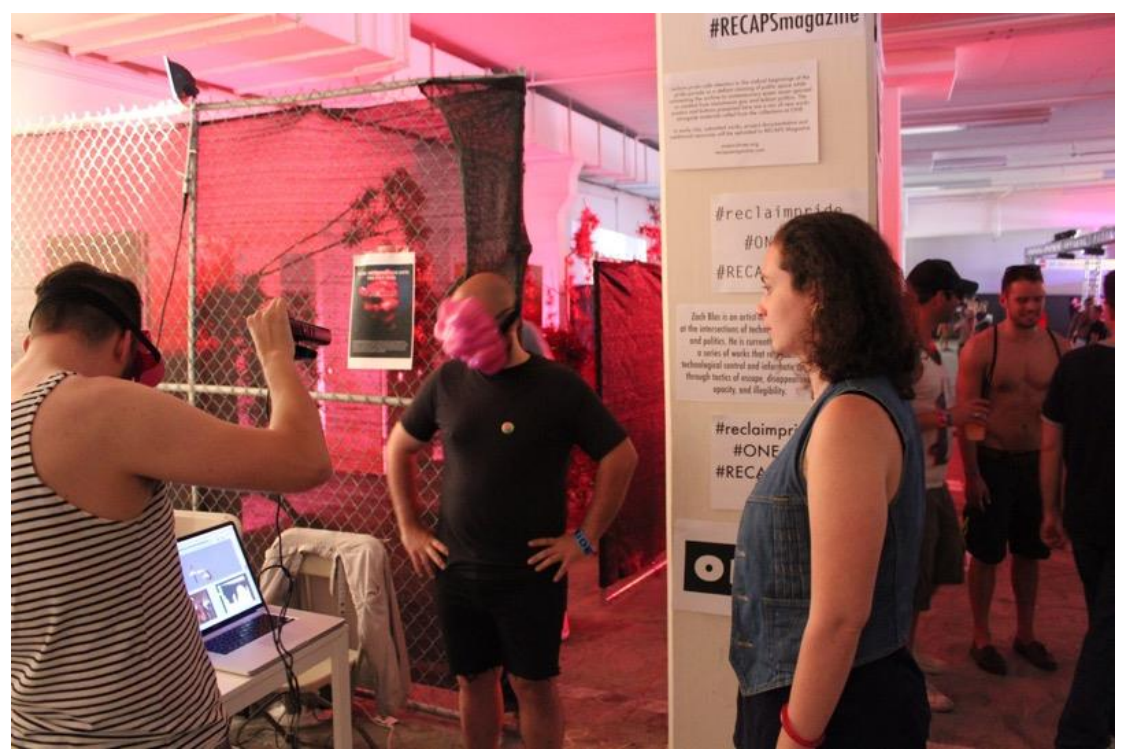

Fig. 2. Facial Weaponization Suite: Fag Face Scanning Station reclaim: pride with the ONE Archives and RECAPS Magazine Christopher Street West Pride Festival, West Hollywood, CA, 8 June 20I3, photo by David Evans Frantz. Reproduced with the kind permission of Zach Blas.

\section{Facial Weaponization SUITE}

The Facial Weaponization Suite is an intermedial art series by Zach Blas that is intended to protest against biometric facial recognition and that comprises several masks, but also performances, workshops, photographs, and a video. The idea of each mask is to superimpose facial data to create an abstract shape, unrecognizable as a face. The first mask in the series is the Fag Face Mask (2012) (see Fig. 2), which was created at a workshop in Los Angeles in the fall of 2012 and which, supposedly, merges exclusively the facial data of queer men. The idea for the mask was sparked by a 2008 study conducted at Tufts University that claimed that participants could correctly 
identify, with an above-chance probability, the sexual orientation of a group of men by simply looking at pictures of these men's faces for as briefly as 50 milliseconds. ${ }^{6} \mathrm{So}$ far, Blas has created four masks: a black, a blue, and a silver one, in addition to the pink Fag Face Mask. The black mask "addresses a tripartite conception of blackness, split between biometric racism (the inability to detect dark skin), the favoring of black in militant aesthetics, and black as that which informatically obfuscates." 7 The blue mask "engages feminism's relations to concealment and imperceptibility, taking veil legislation in France as a troubling site that oppressively forces visibility." "The silver mask (see Fig. I) "considers biometrics deployment as a security technology at the Mexico-US border and the nationalist violence it instigates." Every mask was created by overlaying the faces derived from workshop participants. The workshops discussed global and local politics of biometrics and face recognition, but also exposed the participants to a facial scan using a Kinect, originally a motion sensing device for Xbox 360 , in order to develop a $3 \mathrm{D}$ model of each face. ${ }^{10}$ The facial data was assembled in a $3 \mathrm{D}$ modelling software in order to produce the amorphous surface of each mask that no longer resembles a human face.

In a 2016 lecture Blas described this process as "a play with the layers on the zaxis." "It is clear, therefore, that he does not form an average of these faces or make them otherwise intelligible, but allows them to overlap, to penetrate each other, and to pile up. The workshop participants also decided to perform "a masked public intervention [...] that aims to highlight inequalities of biometric facial recognition, draw attention to local uses and deployments, and experiment with collectivizing and

${ }^{6}$ Nicholas O. Rule and Nalini Ambady, "Brief Exposures: Male Sexual Orientation Is Accurately Perceived at $50 \mathrm{ms,"} \mathrm{Journal} \mathrm{of} \mathrm{Experimental} \mathrm{Social} \mathrm{Psychology,} \mathrm{vol.} \mathrm{44,} \mathrm{2008,}$ p. IIOO-IIO5,

https://tspace.library.utoronto.ca/bitstream/1807/33129/I/Rule\&Ambady(2008_JESP).pdf (accessed is September 2018).

7 Blas, 2014 .

8 Zach Blas, Presentation of the Facial Weaponization Suite, 20II-20I4, http://www.zachblas.info/works/facial-weaponization-suite/ (accessed I2 June 20I8).

9 Ibid.

ro Zach Blas, "Escaping the Face: Biometric Facial Recognition and the Facial Weaponization Suite," Media-N, CAA Conference Edition, vol. 9, no. 2, Summer 2013, http://median.newmediacaucus.org/caa-conference-edition-2013/escaping-the-facebiometric-facial-recognition-and-the-facial-weaponization-suite/ (accessed I2 June 2018).

"Zach Blas, To Mask and to Hide - Maskieren und Verstecken: Vortrag von Zach Blas, lecture given at the Zentrum für Kunst und Medien Karlsruhe / Institut für Bildmedien, 2016, https://zkm.de/media/video/maskieren-und-verstecken-o (accessed I2 June 20I8). 
defacing the face, " ${ }^{12}$ which can be a tableau vivant (black mask), a performance (blue mask), or a "Procession of Biometric Sorrows" (silver mask) (see Fig. 4).

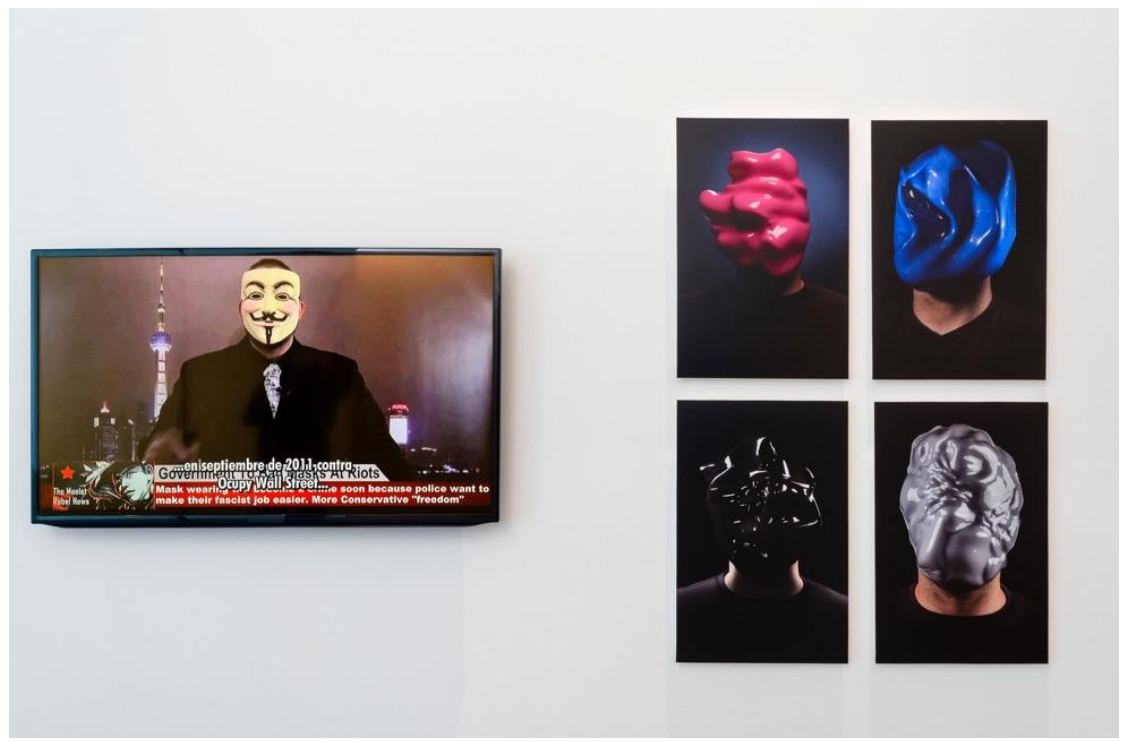

Fig. 3. Installation detail, The Theory of Colour, curated by Cuauhtémoc Medina, Helena Chávez, and Alejandra Labastida, Museo Universitario Arte Contemporáneo (MUAC), Mexico City, Mexico, 27 September 2014- 7 February 2015. Reproduced with the kind permission of Zach Blas.

In the context of the accompanying exhibition, the masks and stylized photographs of the masks being worn are presented next to photographs of the performances or protests staged by the workshop participants, and to a video called Facial Weaponization Communiqué: Fag Face (2012) (see Fig.3). Showing surveillance and news footage next to the Fag Face Mask, with presumably Blas himself wearing the mask, this video introduces the issues surrounding biometric recognition, placing it within a greater narrative of biometric control and biometric surveillance. It states that technologies like facial recognition and iris scans, employed for example at national borders or at protests, seek to manufacture "the perfect automated identification tools that can successfully read a core identity off the body." "In response to these techniques, Blas calls for "weaponizing the face through

\footnotetext{
${ }^{12}$ Blas, 2013.

${ }_{13}$ Zach Blas, Facial Weaponization Communiqué: Fag Face, 2012, video, 8 min. II sec., http://www.zachblas.info/works/facial-weaponization-suite/ (accessed I2 June 20I8).
} 
masks." ${ }^{14}$ The video goes on: "In solidarity with Anonymous, Pussy Riot, and the Zapatistas, we embrace the power of the collective face, we make our faces common with the mask and become a faceless threat, the queer opaque." Is

\section{Algorithmic Governmentality}

Blas positions the Facial Weaponization Suite against surveillance, especially biometric surveillance, and describes the tactic as becoming unrecognizable. In his text "Informatic Opacity," he suggests that surveillance in general follows a logic of making visible. However, Rouvroy and Berns disagree that surveillance is always about increasing visibility. They claim, rather, that the implementation of big data surveillance, which they call algorithmic governmentality-probably the most common form of implementation at the moment-circumvents the individual.

But first, what is algorithmic governmentality? It describes the "automated collection, aggregation and analysis of big data so as to model, anticipate and preemptively affect possible behaviours." ${ }^{16}$ Rouvroy and Berns refer, for instance, to the customization of advertisements, products, and offers, but also to decision-making based on big data, such as whether or not one receives a loan or whom to employ or promote based on one's profile. Derived from the data constantly created by various activities, spanning from searching the internet to walking in the park, ${ }^{17}$ profiles are basically patterns or correlations found in diverse data that allow predictions on future behaviours following the logic of: "others who are similar to you have acted like this in the past so it is somewhat probable that you will act in a similar way." Algorithmic governmentality describes the attempt to use these inductive and probabilistic patterns to safeguard investments against unforeseen incidents. Thus, it is akin to what Michel Foucault presents as the aim of governmentality: "Making possible, guaranteeing, and ensuring circulations: the circulation of people, merchandise, and air, et cetera." ${ }^{18}$ Algorithmic governmentality uses big data surveillance to smooth circulation and avoid any unexpected bumps along the way.

Algorithmic governmentality appears to be a technique based on specific knowledge about each individual, implementing a truth about each individual based

\footnotetext{
${ }^{14}$ Ibid.

is Ibid.

${ }^{16}$ Rouvroy and Berns, 2013, para. Io.

${ }_{17}$ David Lyon, Surveillance after Snowden, Cambridge, UK, Polity Press, 2015, p. 9.

${ }^{18}$ Michel Foucault, Security, Territory, Population: Lectures at the College de France, 197778, trans. Graham Burchell, Basingstoke, UK, Palgrave Macmillian, 2007, p. 29.
} 
on their personal data. Rouvroy and Berns, however, argue that algorithmic governmentality "circumvents and avoids reflexive human subjects, feeding on infraindividual data which are meaningless on their own, to build supra-individual models of behaviours or profiles." ${ }^{9}$ Thus, making individuals' interactions with the digital milieu measurable does not imply that individuals themselves become more visible or more intelligible. ${ }^{20}$ In terms of infra-individual data: data has to be put into comparison with other data, therefore it is stripped of the context from which it emerges and "cleansed of any inherent meaning." ${ }^{2 I}$ While personal data like the content of a call might be very revealing, it has no value for this governance technique as long as it is not made comparable, i.e. generalized. In fact, the objectivity of the data and its analysis is constructed as the exclusion of intentionality and subjectivity. It is said to be objective because nobody has to give an account of their actions or intentions, nobody has to fill out any questionnaires, nobody has to interpret these accounts. Data itself is, according to Rouvroy, "infralinguistic [infralangagiers]" 22 and a-significant. Furthermore, data analysis is automated to find patterns or correlations uninformed by a pre-existing hypothesis, neither interpreting the data nor looking for a causal explanation. ${ }^{23}$ Additionally, the fact that profiles are supraindividual shows that personalization does not inevitably imply individualization nor subjectivation. The patterns or profiles derived from data analysis are not meant to be perfect representations of users, but to be sufficient indicators for a strategy of action (for example, a bank's strategy on lending where success is measured by an increased credit rate and a decreased credit loss). They function under a regime of operationality rather than a regime of truth: the results have to be reliable rather than accurate. $^{24}$

Consequently, Rouvroy describes the relationship between the individual and the profile as a contagion, rather than a close identification, as a "propagation from nearby to nearby [propagation de proche en proche]" ${ }^{25}$ revealing not an individual character, but the people, stores, films, or music one interacts with,

19 Rouvroy and Berns, 2013, para 1o.

${ }^{20}$ Antoinette Rouvroy, "Homo juridicus est-il soluble dans les données ?," in Elise Degrave, Cécile de Terwangne, Séverine Dusollier, Robert Queck (eds.), Law, Norm and Freedoms in Cyberspace / Droit, normes et libertés dans le cybermonde: Liber Amicorum Yves Poullet, Brussels, Lacier, coll. « Crids », 2018, p. 424.

${ }^{21}$ Rouvroy and Berns, 2013, para 6.

${ }^{22}$ Rouvory, 20I8, p. 424.

${ }^{23}$ Rouvroy and Berns, 2013, paras. 5-6.

24 Rouvroy, 20I8, p. 438.

25 Ibid., p. 424. 
frequents, watches, and listens to. According to Rouvroy and Berns, algorithmic governmentality concerns relations-those one has with others and with the environment at large-which are transcribed as data, to allow actions on relations (the relation one has with advertisers, one's bank, one's employer, and so on). ${ }^{26}$ Algorithmic governmentality is a "governance of relations" 27 and thus never implicates a singular individual, but always a collective of at least two. Hence, this kind of employment of big data surveillance described by Rouvroy and Berns has to be differentiated from public, camera-based or biometric surveillance, and even databased phenomena like the Quantified Self movement (which Rouvroy and Berns describe as an "individual re-appropriation" ${ }^{28}$ of data) or the social score system dawning in China. In all of them the individual is present and made subject by being watched or measured. On the other hand, the process of algorithmic governmentality, the aggregation of infra-individual data to create a supra-individual profile, does not render the individual visible, but rather makes uncertainties manageable.

In this non-subjectivation we might find the reason why this kind of surveillance faces little resistance from the broader public-in fact, usage ${ }^{29}$ and number of users ${ }^{30}$ of Facebook even increased after its latest scandal in 2018 when it was revealed that Cambridge Analytica had apprehended the data of millions of the site's users. Following an analysis of Foucault and Judith Butler, I argue that the reason for this is that only through a prior subjectivation one can engage with the subjugating power. While resistance to power is often thought of as a fight against power or those in power, Foucault has shown that resistance can only arise through an intrinsic relationship with power. ${ }^{31} \mathrm{He}$ argues that subjects, as the ones who could resist power, do not simply exist, but are made to exist through a process of

${ }^{26}$ Rouvroy and Berns, 2013, para 27.

27 Ibid.

${ }^{28}$ Ibid., footnote 15.

${ }^{29}$ Jake Kanter, "The Backlash That Never Happened: New Data Shows People Actually Increased Their Facebook Usage after the Cambridge Analytica Scandal,” Business Insider Deutschland, 20 May 20I8, https://www.businessinsider.de/people-increased-facebookusage-after-cambridge-analytica-scandal-20I8-5? $\mathrm{r}=\mathrm{US} \& \mathrm{IR}=\mathrm{T}$ (accessed I2 June 20I8).

${ }^{30}$ Sheera Frenkel and Kevin Roose, "Facebook's Privacy Scandal Appears to Have Little Effect on Its Bottom Line," The New York Times, 25 April 2018, https://www.nytimes.com/2018/04/25/technology/facebook-privacy-earnings.html (accessed I2 June 20I8).

${ }^{31}$ See Maria Muhle, Eine Genealogie der Biopolitik: Zum Begriff des Lebens bei Foucault und Canguilhem, Munich, Wilhelm Fink, 2013, p. 275. 
subjectivation, a form of power that "applies itself to immediate everyday life which categorizes the individual, marks him by his own individuality, attaches him to his own identity, imposes a law of truth on him which he must recognize and which others have to recognize in him. It is a form of power which makes individuals subjects." ${ }^{32}$

To be in this way subjugated might be seen as restrictive, but at the same time it is a prerequisite to critique, or what Foucault calls a "reverse-discourse." In Volume I of History of Sexuality, Foucault exemplifies this with reference to homosexuality. According to him, from the nineteenth century onwards, homosexuality has been constructed through discourse as a species or a personality, whereas previously this practice was seen as a "temporary aberration." 33 While this discourse enhanced social control on homosexuality and on other practices perceived as perverted, "it also made possible the formation of a 'reverse' discourse: homosexuality began to speak on its own behalf, to demand that its legitimacy or 'naturality' be acknowledged, often in the same vocabulary, using the same categories by which it was medically disqualified." 34 Consequently, Butler concludes, reading Foucault together with Sigmund Freud, that "only by occupying-being occupied by-that injurious term [that allows one to "come into social being" 35 in the first place] can I resist and oppose it, recasting the power that constitutes me as the power I oppose." ${ }^{36}$ She notices that "[i]n his later interviews, Foucault suggests that identities are formed within contemporary political arrangements in relation to certain requirements of the liberal state, ones which presume that the assertion of rights and claims to entitlement can only be made on the basis of a singular and injured identity" ${ }^{37}$ : resistance and critique thus come easy when "my" privacy is in jeopardy, when "my" personal data is implicated. In that case, I would be able to argue that an injustice was inflicted on me. But the discursive site of personal privacy and personal data is an ill fit for algorithmic governmentality, which relies on a great quantity of data, but not on the personality of data.

${ }^{32}$ Michel Foucault, "The Subject and Power," Critical Inquiry, vol. 8, no. 9, Summer 1982, p. $78 \mathrm{I}$.

33 Michel Foucault, The History of Sexuality: Volume I: An Introduction, trans. Robert Hurley, New York, Random House, 1978, p. 43.

34 Ibid., p. IoI.

35 Judith Butler, The Psychic Life of Power: Theories in Subjection, Stanford, Stanford University Press, 1997, p. I04.

${ }^{6}$ Ibid.

37 Ibid., p. Ioo. 
That subjectivation is a prerequisite for resistance is especially evident when such a process is missing. Butler describes the situation of lesbians at the time of one of her early essays in 1991, "Imitation and Gender Insubordination," as a situation not of subjugation and suppression, but of oppression that works through the "constitution of a domain of unviable (un)subjects - abjects, we might call themwho are neither named nor prohibited within the economy of law." ${ }^{8} 8$ While gay men at that time had already been the object of prohibition, Butler argued that lesbianism had not yet made it into the thinkable and the nameable and thus lacked "a discursive site from which something like a reverse-discourse can be articulated." ${ }_{39}$ She asks: "How, then, to 'be' a lesbian in a political context in which the lesbian does not exist?" ${ }^{\circ}$ Rouvroy and Berns argue that a similar situation is evident in algorithmic governmentality: it produces no subjectivation and thus evades or complicates the production of discursive sites that allow for reflexivity, critique, and recalcitrance. ${ }^{4 \mathrm{I}}$ With the circumvention of the individual, the intrinsic relationship to power through which resistance could arise is missing within algorithmic governmentality.

\section{DISIDENTIFICATION}

Since algorithmic governmentality does not produce the site from which to critique it or from which to engage in a reverse-discourse, it seems necessary to produce such a site otherwise. I propose that Blas' Facial Weaponization Suite establishes such a production through what one might call the inhabitation of the profile, taking the supra-individual patterns and turning them into discursive sites. In this way, it points to a tactic of engagement with this elusive form of governance: not along an individual standpoint, but through the profile, on behalf of the profile, by being the profile.

In the previously mentioned lecture, speaking about the Fag Face Mask, Blas describes the idea underlying the masks:

At first I began from a really funny place: If these studies claim that you can successfully determine whether one person is gay or straight, what would

${ }^{38}$ Judith Butler, "Imitation and Gender Insubordination," in Henry Abelove, Michèle Aina Barale, David M. Halperin (eds.), The Lesbian and Gay Studies Reader, New York, Routledge, 1993, p. 312.

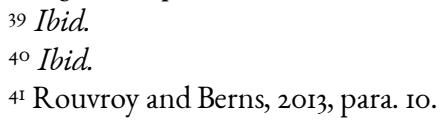


happen if you wear twenty gay faces which would supposedly make you super-gay. But, of course, what happens is that you end up getting this aesthetic result that is abstract. You cannot be biometrically recognized or let alone be detected as a human..$^{22}$

By aggregating facial data, the Facial Weaponization Suite not only resists biometric facial recognition, but also enters into a quite different relation with algorithmic governmentality. This movement of resisting the one, but thus entering into a relationship with the other might be explained with a reference to Allan Sekula's famous essay on "The Body and the Archive" where he contrasts the system of Bertillon with that of Galton. While both the Paris police official Alphonse Bertillon and the English statistician Francis Galton worked at the intersection of photography and statistics in the nineteenth century, Sekula describes their results as "strikingly different." ${ }^{43}$ Bertillon was especially interested in a proper system of identification that could correctly re-identify criminals once registered. Therefore, he sought to set up a system to measure, photograph, categorize, and catalogue the body of criminals. But since the system was indented only to connect individuals to an existing file, thus for example identifying repeat offenders, "the criminal body expressed nothing [for Bertillon]. No characterological secrets were hidden beneath the surface of this body." ${ }^{4}$ Galton, on the other hand, is interested not in the (re-)identification of an individual, but in the common traits apparent in the bodies of family members, criminals, healthy and sick men and women. To discover them he makes composites of individuals, giving each only a fractional exposure. As Sekula describes:

That is, if a composite were to be made from a dozen originals, each would receive one-twelfth of the required total exposure. Thus, individual distinctive features, features that were unshared and idiosyncratic, faded away into the night of underexposure. What remained was the blurred, nervous configuration of those features that were held in common throughout the sample.45

\footnotetext{
$4^{2}$ Blas, 2016.

${ }^{43}$ Allan Sekula, "The Body and the Archive," October, vol. 39, Winter 1986, p. I8.

44 Ibid., p. 30.

45 Ibid., p. 47.
} 
Galton claims that these composites are a form of "pictorial statistics," 46 saying that

[c]omposite pictures are [...] much more than averages; they are rather the equivalents of those large statistical tables whose totals, divided by the number of cases and entered on the bottom line, are the averages. They are real generalizations, because they include the whole of the material under consideration. The blur of their outlines, which is never great in truly generic composites, except in unimportant details, measures the tendency of individuals to deviate from the central type. ${ }^{47}$

While Bertillon wants to establish an archive of criminals, Galton wants to collapse the whole archive into a single picture. ${ }^{48}$ The resemblance of this approach to Blas' superimposition of queer men's faces to produce the Fag Face Mask should be clear. But it is also similar to big data surveillance. In the same way that big data surveillance aims to find correlations in data, Galton tries to find correlations or patterns in faces. However, one needs to point out that the data Galton used was homogenous whereas in big data surveillance it is necessarily heterogenous. Through prior selection of data, for example "a combination of twelve officers and eleven enlisted men of the Royal Engineers," 49 one arrives at statements that the composite pictures show the ideal or improved English man, "the Jewish type,"so or Blas' "super-gay." Only through prior selection can the conclusion be drawn that the shared features are the result of being Jewish, gay, or an "enlisted man of the Royal Engineers." 5 This prior selection is, however, incompatible with algorithmic governmentality in which data is employed to "speak for [itself]" 52 to find connections between interactions so that one can predict future actions based upon prior ones, rather than discovering a type. Thus, there is an apparent shift in Blas' work with regards to the later masks when he no longer defines the group from which the facial data has been derived.

It is mostly with these later masks in mind that, in relation to algorithmic governmentality, the Facial Weaponization Suite seems to develop a tactic of disidentification distinct from the relation of outright resistance it has with biometric

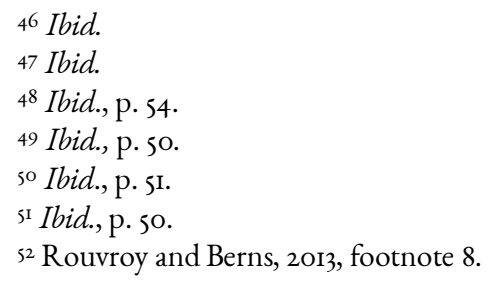


facial recognition. Blas himself evokes the concept of disidentification by queer

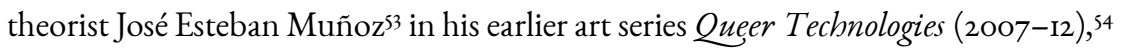
calling his strategy at the time a "disidentification with technology." 55 Queer Technologies consists of works imitating products like an user's manual entitled Gay Bombs (2008), a queer programming anti-language, or adapters converting not from female to male, but from female to $\mathrm{CEO}$ or from male to butch. The aim is to connect queerness to a binary technology (male/female, hole/pin, zero/one), to allow for the survival of the queer by exploiting, hacking, and recoding technology.

Muñoz introduces disidentification as a "survival strategy" 56 in response to the precarious status of minorities, a status where because of ideological restrictions and stigmatizations identification is not always possible. ${ }^{57}$ Minorities do not necessarily face physical extinction (although of course that might be, and indeed is very often, the case), but are made extinct by being cast as abjects - to borrow the term from Butler-as unviable unsubjects lacking social existence. As in algorithmic governmentality, the problem is not subjectivation, but the lack of it, as exemplified by the experience of Marlon Riggs as a black gay man is a world where gayness is linked to whiteness. In a documentary entitled Tongues United, Riggs describes the experience of being an invisible man in the "great gay mecca" 58 : "[...] I had no shadow, no substance. No history, no place. No reflection." ${ }^{99}$ Muñoz argues that to establish one's existence, to survive, one has to "[work] on and against a dominant ideology," ${ }^{60}$ relying on dominant ideology for social meaning, but with the

53 Unacknowledged by Muñoz, the concept of disidentification also appears in the work of Jacques Rancière. He describes, for example, the moment when, during his trial in 1832 , the revolutionary Auguste Blanqui insisted that his profession was "proletarian" as a disidentification, referring to the subjectifying of a collective that is in no way identifiable with a social group. Jacques Rancière, Disagreement: Politics and Philosophy, trans. Julie Rose, Minneapolis, MN, University of Minnesota Press, 1999, p. 37.

54 Zach Blas, Queer Technologies, mixed media installation, book, CD, packaged adapters, videos with audio, $8 \mathrm{~min} .34 \mathrm{sec}$ and Io min. 24 sec., 2007-2012, http://www.zachblas.info/works/queer-technologies/ (accessed I9 September 2018).

ss Queer Technologies, Inc., “Gay bombs: User's manual,” http://www.zachblas.info/wpcontent/uploads/2016/03/GB_users-manual_web-version.pdf, 2008, (accessed I9 September 2018).

${ }^{66}$ José Esteban Muñoz, Disidentifications-Queers of Color and the Performance of Politics, Minneapolis, MN, University of Minnesota Press, 1999, p. 4.

57 Ibid., p. 7.

${ }^{58}$ Quoted in Ibid., p. 9.

59 Quoted in Ibid.

6o Ibid., p. II. 
requirement that it turns first into an "inhabitable and potentially enabling identity site." ${ }^{61} \mathrm{He}$ writes:

Disidentification is about recycling and rethinking encoded meaning. The process of disidentification scrambles and reconstructs the encoded message of a cultural text in a fashion that both exposes the encoded message's universalizing and exclusionary machinations and recircuits its workings to account for, include, and empower minority identities and identifications. Thus, disidentification is a step further than cracking open the code of the majority; it proceeds to use this code as raw material for representing a disempowered politics or positionality that has been rendered unthinkable by the dominant culture. ${ }^{62}$

Consider, for example, an incident that Muñoz recounts taking place during his late teens. He came home one day wearing new, bright-red sunglasses. His father saw the new glasses and, "with equal measures of disgust and exhaustion in his voice,"63 called them "picuo." Not knowing what this old-fashioned Cuban word meant, but sensing its shaming properties, Muñoz assumed that "I was being called the faggot that I was about to become." ${ }^{64} \mathrm{He}$ asked his mother, who explained that "picuo" means "tacky." Muñoz goes on to write: "So picuo did not mean what I thought (and secretly hoped) it would mean." "Ss One stumbles over the three words in brackets. Why did Muñoz secretly hope that his father had called him a faggot? Who would hope to be insulted and shamed? Muñoz seems to sense here that even though shaming is meant to restrict identification, being called a faggot would also have acknowledged his desires, making them in a sense more real. He insists that shame, while being an oppressive and dangerous cultural force that cannot simply be negated, can be "incorporated, mediated, and transfigured." ${ }^{66}$ As Eve Kosofsky Sedgwick claims, shame is "available for the work of metamorphosis, refiguration, transfiguration, of affective and symbolic loading and deformation, but perhaps all too potent for the work of purgation and deontological closure." ${ }^{67}$ Disidentification operates on the premise that something like shame can be recycled to overcome the restrictions intended by it
${ }^{6}$ Ibid., p. 194.
${ }^{62}$ Ibid., p. 3I.
${ }_{63}$ Ibid., p. 194.
64 Ibid., p. 195.
6s Ibid.
${ }^{6}$ Ibid., p. 55.
${ }_{7}$ Eve Kosofsky Sedgwick, Touching Feeling: Affect, Pedagogy, Performativity, Durham, Duke University Press, 2003, p. 63. 
while at the same time maintaining the affirmation entangled with it. The word queer is itself a good example of such a process where a once-shaming epithet was taken back. In the same way, algorithmic governmentality could be understood to offer the material for constructing a discursive site, which it does not itself produce-material that can be appropriated and turned inhabitable.

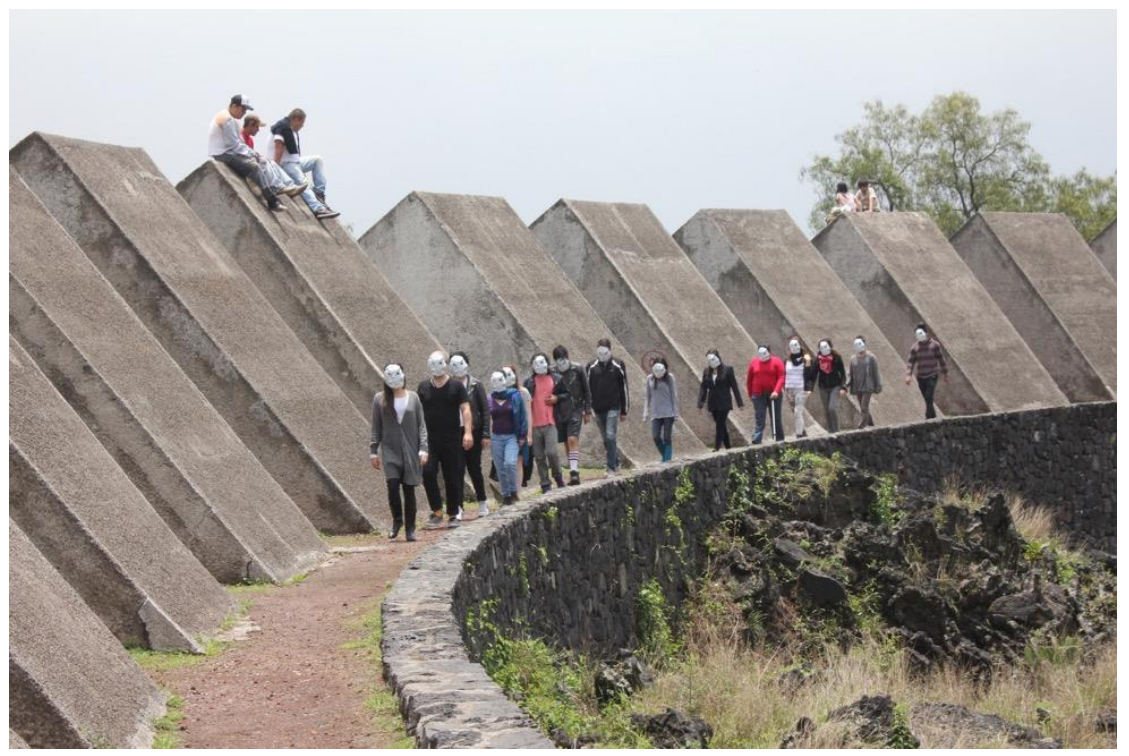

Fig. 4. Facial Weaponization Suite: Procession of Biometric Sorrows, MUAC Mexicoistepis June 20I4, photo by Orestes Montero Cruz. Reproduced with the kind permission of Zach Blas.

\section{MASKING}

I argue, therefore, that the aggregation and combination of facial data through which Blas' masks are created, translated by Blas as the idea of wearing "twenty faces," ${ }^{68}$ mimics the process of constructing a profile, itself also a collective or something "supra-individual" 69 in Rouvroy and Berns' term, a combination of diverse data. Through the imitation of the process, the profile is appropriated. But it is only made inhabitable when the resulting combinations are turned into a physical mask via ${ }_{3} \mathrm{D}$ printing such that they can be worn in performances and at protests (see Fig. 4). A mask not only hides the face beneath, but also shows something. In theater it represents a character; in rituals it can be the manifestation of the god or the animal

68 Blas, 2016.

${ }^{69}$ Rouvroy and Berns, 20I3, para. Io. 
depicted. A mask establishes. In an essay focusing on political protesters who wear masks, and paralleling Blas in invoking the Zapatistas and Anonymous, Lone Riisgaard and Bjørn Thomassen refer to Marcel Mauss and his discussion of personhood:

Describing the notion of personhood among the Zuni, Mauss insisted that we should not consider the wearing of a mask as different from any "real" person behind the mask. The person is the mask, and in exactly this Maussian sense the mask can be considered a "technique of the body." This understanding is only possible if we attempt to move outside a moderncentric worldview. The person is a human being, but it is not based on a Kantian fiction of "autonomy," quite the contrary: "persona" derives from the Latin verb "per/sonare," i.e. to "sound through." The mask is something spoken through. The mask does not conceal: it gives voice. The mask does not hide the subject: it constitutes subjecthood-also related to the literal and original sense of subjectivity as being "thrown under" (sub/jectum). $7^{\circ}$

The video Facial Weaponization Communiqué: Fag Face gives evidence to the Maussian claim that "the person is the mask" ${ }^{71}$ by presenting a continuously shifting, speaking Fag Face Mask. In the video, the mask has its own metallic, computergenerated female voice (while Blas, wearing the mask, speaks with a similarly sounding, but male, voice), telling the viewers about the inequalities embedded within biometric technology and calling for a queer opacity. Indeed, in his 2016 lecture Blas refers to an earlier video (part of which is also included at the very end of the Facial Weaponization Communiqué: Fag Face) in which the mask is depicted as a "living, dynamic thing that talks." 72

What is avoided in algorithmic governmentality is therefore present in Blas' mask: the production of a subject and a discursive site. "Carnival, as political power, is therefore a technique of subjectivation, and it is this technique-ancient and novel-that the sheer putting on of the mask evokes and operates," Riisgaard and Thomassen argue. ${ }^{73}$ The mask is not a barrier, but a communicative tool that can

$7^{\circ}$ Lone Riisgaard and Bjørn Thomassen, "Powers of the Mask: Political Subjectivation and Rites of Participation in Local-Global Protest," Theory, Culture, Society, vol. 33, no. 6, 20I6, p. 8I.

${ }^{71} \mathrm{Ibid}$.

72 Blas, 2016.

73 Riisgaard and Thomassen, 20I6, p. 88. 
create a communicative opening, though communication is here not to be understood as the rational discourse that Jürgen Habermas, among others, imagined. ${ }^{74}$ According to Roger Caillois, the perception of the mask as signifying a real presence in its own right and a way to incorporate this presence is premodern. It has been replaced by a modern notion that regards the mask as nothing more than a way to hide the wearer's identity, in which case, the mask could easily be substituted by a handkerchief.75 Contrary to Caillois, Riisgaard and Thomassen insist that in current protest movements, from the Zapatistas to Anonymous, this premodern ritual power resurfaces, not as a religious belief but as a way to form a collective, to create participation by everyone wearing the same $\mathrm{face}^{76}$ or, as described in the Facial Weaponization Communiqué with reference to the Zapatistas, to "hide their faces so that they may be seen." 77

Relating the Facial Weaponization Suite to algorithmic governmentality thus reveals not just a tactic of becoming unrecognizable, but a way to inhabit the profile by constructing a collective face and thus to establish a relationship with algorithmic governmentality in order to question and protest it. Since the profile is present in this governmental technique, while the individual is absent, it is along these lines that resistance can be envisioned through the Facial Weaponization Suite. Through the masks and their performative wearing the representation of the profile is turned into a manifestation, thus establishing the profile as a discursive site, allowing to take on the role of the profile, to literally wear it, and thereby inhabiting the profile.

\section{CONCLUSION}

I have argued that if one disagrees with Blas' assumption that surveillance generally follows a logic of making visible, as I have done in this article, and if one positions the Facial Weaponization Suite instead in relation to algorithmic governmentality, a tactic of disidentification becomes apparent, which develops an engagement with algorithmic governmentality by inhabiting the profile. While according to Rouvroy and Berns, algorithmic governmentality produces no subjectivation, and thus, as I have shown in reference to Foucault and Butler, offers no discursive site from which to critique it, the Facial Weaponization Suite points to a tactic of establishing such a site. With the superimposition of faces, it resembles the

74 Ibid., p. 77.

75 Roger Caillois, Man, Play and Games, transl. Meyer Barash, Urbana, IL, University of Illinois Press, 200I, p. I30.

${ }^{76}$ Riisgaard and Thomassen, 2016, p. 78.

77 Blas, 2 OI2. 
famous composite pictures by Galton, but without prior selection of (facial) data Blas' later masks parallel more closely the process behind creating a profile. By making this superimposition into a physical, wearable mask, they participate in the ritual power of the mask as a communicative tool that manifests what it represents and shows rather than hides. While the critique against big data surveillance is often linked to personal privacy and personal data, this reading of the Facial Weaponization Suite conceives of a necessarily collective politics-not holding on to one's singular, unique identity, but rather wearing multiple faces at once. 


\title{
Inhabiting the Profile: Zach Blas' Facial Weaponization Suite
}

\author{
Sebastien Althoff, Institute for Media Studies, Ruhr- \\ UNIVERSITY BOCHUM
}

\section{ABSTRACT}

This article places Zach Blas' Facial Weaponization Suite (2OII-2014) in relation to the notion of algorithmic governmentality in order to reveal a tactic of disidentification. Algorithmic governmentality refers to the implementation of big data surveillance that does not render individuals visible, but rather circumvents them, thereby complicating the possibility of a critical engagement. Such critical engagement, however, can be envisioned through the Facial Weaponization Suite.

\section{RÉSUMÉ}

Cet article considère l'œuvre Facial Weaponization Suite de Zach Blas (2OII-20I4) en relation avec la notion de gouvernementalité algorithmique afin de révéler une tactique de désidentification. Ce qu'on appelle la gouvernementalité algorithmique est l'exécution de la surveillance des individus par les big data, surveillance qui ne rend pas ceux-ci visibles, mais les contourne, compliquant ainsi tout engagement critique. Un tel engagement peut cependant être envisagé à travers la Facial Weaponization Suite.

\section{NOTE BIOGRAPHIQUE}

Sebastian Althoff is a PhD candidate at the Institute for Media Studies at the RuhrUniversity Bochum, in cooperation with the Academy of Fine Arts Munich, and he is a member of the DFG Research Group on Media and Mimesis. In his research he develops the notion of a digital mimicry in response to big data surveillance, referring to Roger Caillois' work on mimicry as well as recent examples of digital art. 